\title{
Postnatal Handling Increases the Expression of cAMP-Inducible Transcription Factors in the Rat Hippocampus: The Effects of Thyroid Hormones and Serotonin
}

\author{
Michael J. Meaney, ${ }^{1}$ Josie Diorio,, ${ }^{1}$ Darlene Francis, ${ }^{1}$ Shelley Weaver, ${ }^{1}$ Joyce Yau, ${ }^{2}$ Karen Chapman, ${ }^{2}$ and \\ Jonathan R. Seckl² \\ ${ }^{1}$ Developmental Neuroendocrinology Laboratory, Douglas Hospital Research Center, Departments of Psychiatry, and \\ Neurology and Neurosurgery, McGill University, Montreal, Canada, H4H 1R3, and 2Molecular Endocrinology Laboratory, \\ Department of Medicine, University of Edinburgh, Edinburgh, Scotland, United Kingdom EH4 2XU
}

Postnatal handling increases glucocorticoid receptor expression in the rat hippocampus, thus altering the regulation of hypothalamic synthesis of corticotropin-releasing hormone and the hypothalamic-pituitary-adrenal response to stress. The effect on glucocorticoid receptor gene expression represents one mechanism by which the early environment can exert a longterm effect on neural development. The handling effect on hippocampal glucocorticoid receptor expression is dependent on peripheral thyroid hormone release and the activation of ascending serotonergic pathways. In primary hippocampal cell cultures, serotonin (5-HT) increases glucocorticoid receptor expression, and this effect appears to be mediated by increased cAMP levels. In the current studies we examined the in vivo effects of handling on hippocampal cAMP-protein kinase $A$ (PKA) activity. In 7-d-old rat pups, we found that (1) postnatal handling increased adenylyl cyclase activity and hippocampal cAMP levels, (2) the effect of handling on cAMP levels was completely blocked by treatment with either propylthiouracil
(PTU), a thyroid hormone synthesis inhibitor, or the 5-HT receptor antagonist, ketanserin, and (3) handling also increased hippocampal PKA activity. We then examined the effects of handling on CAMP-inducible transcription factors. Handling rapidly increased levels of the mRNAs for nerve growth factorinducible factor A (NGFI-A) (zif268, krox24) and activator protein-2 (AP-2) as well as for NGFI-A and AP-2 immunoreactivity throughout the hippocampus. Finally, we found that the effects of handling on NGFI-A and AP-2 expression were significantly reduced by concurrent treatment with either PTU or ketanserin, effects that paralleled those on cAMP formation. NGFI-A and AP-2 have been implicated in the regulation of glucocorticoid receptor expression during development. Thus, these findings suggest that postnatal handling might alter glucocorticoid receptor gene expression via cAMP-PKA pathways involving the activation of NGFI-A and AP-2.

Key words: glucocorticoid receptor; neural development; cAMP; thyroid hormones; serotonergic pathways; rat
The adrenal glucocorticoids comprise a frontline of defense for mammalian species under conditions of stress, and along with the catecholamines they serve to mobilize the production and distribution of energy substrates during stress (Brindley and Rolland, 1989). These endocrine responses are stimulated by the stressinduced release of corticotropin-releasing factor (CRF) and/or arginine vasopressin (AVP) from hypothalamic neurons (Plotsky, 1991). The inhibitory regulation of CRF synthesis is achieved, in part, through a negative feedback loop whereby circulating glucocorticoids act at various neural sites to decrease CRF and AVP gene expression (De Kloet et al., 1998). Such inhibitory effects are initiated via an interaction between glucocorticoids and an intracellular receptor, including both the glucocorticoid and mineralocorticoid receptor.

The development of the hypothalamic-pituitary-adrenal (HPA)

Received May 5, 1999; revised Feb. 2, 2000; accepted Feb. 22, 2000.

This study was supported by a research grant from the Medical Research Council of Canada (MRCC) (M.J.M.) and by a NATO Research Collaboration grant (M.J.M., J.R.S.). M.J.M. is an MRCC Senior Scientist, and J.R.S. is a Wellcome Trust Senior Fellow. We thank Dr. P. Mitchell for the AP-2 cDNA, Dr. J. Milbrandt for the NGFI-A and NGFI-B cDNAs, Dr. M. Seckl for the cJUN cDNA, and Dr. T. Curran for the cFOS cDNA.

Correspondence should be addressed to Michael J. Meaney, Douglas Hospital Research Center, 6875 LaSalle Boulevard, Montréal, Québec, Canada H4H 1R3. E-mail: mdmm@musica.mcgill.ca.

Copyright () 2000 Society for Neuroscience $0270-6474 / 00 / 203926-10 \$ 15.00 / 0$ response to stress is permanently altered by early environmental events. Adult animals exposed to short periods of postnatal handling during the first week of life show more modest plasma $\mathrm{ACTH}$ and corticosterone response to a wide range of stressors (Meaney et al., 1996). This handling effect persists throughout the life of the animal (Meaney et al., 1988) and is accompanied by decreased hypothalamic CRH and AVP expression (Plotsky and Meaney, 1993; Viau et al., 1993; Francis et al., 1996). Postnatal handling increases glucocorticoid receptor gene expression in all cell fields of the hippocampus (O'Donnell et al., 1994), a region that has been strongly implicated as a critical site for glucocorticoid negative feedback regulation (Jacobson and Sapolsky, 1991; Herman and Cullinan, 1997; De Kloet et al., 1998) and thus enhances the tonic inhibition exerted over hypothalamic $\mathrm{CRH} /$ AVP synthesis (Meaney et al., 1989). These results and others (for review, see Meaney et al., 1996) suggest that the increase in glucocorticoid receptor sites in the hippocampus is a critical feature for the handling effect on HPA function. Thus, the early environment can contribute to the development of stable individual differences in neuroendocrine responses to stressful stimuli through long-term effects on gene expression.

The effect of postnatal handling on hippocampal glucocorticoid receptor expression appears to be mediated by a handlinginduced activation of the pituitary-thyroid system that, in turn, leads to an increase in activity within ascending serotonergic 
systems during the first week of life (for review, see Meaney et al., 1996). Postnatal handling increases plasma levels of triiodothyronine $\left(\mathrm{T}_{3}\right)$, which increases serotonin $(5-\mathrm{HT})$ turnover at the level of the hippocampus and frontal cortex, regions where glucocorticoid receptor expression is altered by handling (Mitchell et al., 1990a; Smythe et al., 1994). In contrast, handling has no effect on 5-HT turnover in the hypothalamus and amygdala, regions in which there is no effect of handling on glucocorticoid receptor expression (Smythe et al., 1994). In cultured hippocampal neurons, 5-HT increases glucocorticoid receptor expression, and the effect is blocked by ketanserin and mimicked by various serotonergics (Mitchell et al., 1990b, 1992). In vivo, the effects of handling are blocked by concurrent administration of either the thyroid hormone synthesis inhibitor, propylthiouracil (PTU) (Meaney et al., 1987), or ketanserin (Mitchell et al., 1990a).

The effect of 5-HT on glucocorticoid receptor expression in hippocampal neurons appears to be mediated by altered cAMP formation. Thus, in cultured hippocampal neurons there is a strong correlation $(+0.97)$ between the ability of a range of serotonergics to increase glucocorticoid receptor expression and their effects on cAMP levels (Meaney et al., 1994). Glucocorticoid receptor expression is increased by 8-bromo-cAMP as well as by forskolin (Mitchell et al., 1992), and the effects of 5-HT are completely blocked by the protein kinase A (PKA) inhibitor H8 (Mitchell et al., 1990b, 1992). These effects appear to involve altered rates of receptor biosynthesis. The in vivo effects of handling or the in vitro effects of 5-HT are apparent at the level of receptor binding, protein, and mRNA (Mitchell et al., 1990b, 1992; O'Donnell et al., 1994). The in vitro effects of both 5-HT and cAMP manipulations require a minimum of $4 \mathrm{~d}$ of treatment, and the effects of both are blocked by treatment with either cyclohexamide or actinomycin D. Altered rates of cAMP formation are known to affect gene transcription. These cAMP effects appear to be mediated, in part, by a range of cAMP-responsive transcription factors and their interactions with specific DNA binding sites (Imagawa et al., 1987; Habener, 1990; Vallejo, 1994). In the studies reported here we examined the effects of postnatal handling on the expression of a number of such cAMPinducible transcription factors. The hippocampal expression of at least two such factors, AP-2 and NGFI-A (zif268, krox24), is altered by early handling, and these effects are mediated by both thyroid hormone and 5-HT systems. The increase in NGFI-A is particularly interesting because this transcription factor is linked to the steroid receptor superfamily as well as to hippocampal plasticity.

\section{MATERIALS AND METHODS}

Animals. The animals used in these studies were male Long-Evans, hooded rats (Charles River Canada, St. Constant, Quebec), the offspring of dams mated in our animal colony. Handling begun on the day after birth and consisted of removing the mother and then the pups from the cage and placing the pups into a plastic container lined with bedding material for $15 \mathrm{~min}$. The pups and then the mother were then returned to their cage. Handling occurred once per day between 11 A.M. and 2 P.M. The nonhandled (NH) animals were left completely undisturbed throughout this period. Chronic handling refers to animals that were handled once per day until the time they were killed on day 7. Acute handling refers to animals that were handled only on the day they were killed. For all studies, nonhandled $(\mathrm{NH})$ animals were killed by rapid decapitation immediately after removal from the home cage (i.e., $<15$ $\mathrm{sec}$ ). The animals were maintained on a $12 \mathrm{hr}$ light/dark schedule (lights on at 8 A.M.) with free access to food (Purina Lab Chow) and water. The animals used in these experiments were $7 \mathrm{~d}$ of age and were randomly selected from three to six litters per treatment. To disturb litters as little as possible, no effort was made to cull; however, pups from litters of less than 8 or more than 14 pups or litters composed of $<20 \%$ male or female pups were not included in the study.

In one study pups were injected subcutaneously with $2.0 \mu \mathrm{g}$ of ketanserin (Sigma) per gram of body weight or the saline vehicle $(0.05 \mathrm{ml})$ on each of days 1-7 of life. This dose of ketanserin has been shown to block the effects of handling on glucocorticoid receptor binding (Mitchell et al., 1990a). Hypothyroidism was induced using PTU (Sigma) administered through the mother's food ( $0.2 \%$ PTU in lab chow/water "mash") (Meaney et al., 1987) for the first $7 \mathrm{~d}$ of life. Mothers of control litters were fed the mash alone. This PTU treatment has been shown to completely block the effects of handling on glucocorticoid receptor expression (Meaney et al., 1987).

cAMP and protein kinase $A$ activity assays. cAMP levels were determined using a protein binding assay based on the competition between unlabeled cAMP and radiolabeled CAMP for binding to a protein with high specificity for cAMP (Brown et al., 1971). Animals were killed 15 min after handling on day 7 (preliminary studies indicated maximal cAMP levels at this time), and hippocampi were dissected and homogenized by hand on ice and stored at $-80^{\circ} \mathrm{C}$. Hippocampal tissue from two male littermates was pooled to form a single sample, and cAMP levels were determined as previously described (Mitchell et al., 1992) with a 180 pmol concentration of $\left[8-{ }^{3} \mathrm{H}\right]$ cAMP (specific activity $27.78 \mathrm{Ci} / \mathrm{mmol}$; Amersham, Arlington Heights, IL) and a specific cAMP binding protein purified from bovine muscle (Amersham). The data were normalized against protein values [per milligram of protein; Bradford (1976)].

$\left[{ }^{3} \mathrm{H}\right]$ forskolin autoradiography was performed as previously described (Seamon et al., 1984; Worley et al., 1986). Briefly, $15 \mu \mathrm{m}$ sections containing the dorsal hippocampus were incubated at room temperature for $10 \mathrm{~min}$ in $50 \mathrm{~mm}$ Tris- $\mathrm{HCl}$, pH 7.5, $180 \mathrm{~mm}$ sucrose, $10 \mathrm{~mm} \mathrm{MgCl}$ with $20 \mathrm{~nm}\left[{ }^{3} \mathrm{H}\right]$ forskolin (Gelhert et al., 1985) and washed three times in ice-cold buffer for $1 \mathrm{~min}$. Sections were then rapidly dried under a stream of cool, dry air. Nonspecific binding was determined in parallel incubates containing a $20 \mu \mathrm{M}$ concentration of unlabeled forskolin. Autoradiograms were obtained by apposing the slides to tritium-sensitive film (LKB Ultrafilm) along with a series of tritium-based standards (Amersham, Toronto, Ontario) that were used for calibration of the image analysis system (MCID image analyzer, St. Catherines, Ontario).

Protein kinase A activity (phosphotransferase activity) was measured in hippocampal tissue samples from animals killed at various time points after handling on day 7 using an assay based on the phosphorylation of kemptide using the transfer of the $\gamma$-phosphate of $\left[\gamma_{-}{ }^{32} \mathrm{P}\right]$ ATP by PKA (Upstate Biotechnology, Lake Placid, NY). Hippocampi were dissected on ice and stored at $-80^{\circ} \mathrm{C}$. Assay samples were homogenized in $50 \mathrm{~mm}$ Tris-HCl buffer containing $1 \mathrm{~mm}$ EDTA, $1 \mathrm{~mm}$ PMSF, $150 \mathrm{~mm} \mathrm{NaCl}$, and $1 \mu \mathrm{g} / \mathrm{ml}$ aprotinin, $\mathrm{pH} 7.4$, centrifuged at $28,000 \times \mathrm{g}$ for $20 \mathrm{~min}$ at $2^{\circ} \mathrm{C}$, and the supernatants were then reconstituted in homogenization buffer. Aliquots $(10 \mu \mathrm{l})$ of the supernatant were then incubated at $30^{\circ} \mathrm{C}$ for 10 min in $30 \mu \mathrm{l}$ incubation buffer containing $20 \mathrm{~mm}$ MOPS, $25 \mathrm{~mm}$ $\beta$-glycerol phosphate, $5 \mathrm{~mm}$ EGTA, $1 \mathrm{~mm}$ sodium vanadate, $1 \mathrm{~mm}$ dithiothreitol, $75 \mathrm{~mm}$ magnesium chloride, and $125 \mu \mathrm{M}$ ATP (9:1 cold ATP $/\left[\gamma_{-}{ }^{32} \mathrm{P}\right] \mathrm{ATP}, 3000 \mathrm{Ci} / \mathrm{mmol}$ ) with $125 \mu \mathrm{m}$ kemptide (substrate) with or without a mixture of protein kinase inhibitors $(5 \mu \mathrm{M}$ PKC inhibitor peptide and $5 \mu \mathrm{M} \mathrm{R} 24571$; Upstate Biotechnology). Parallel incubates were run excluding either the supernatant or substrate to control for breakdown products or phosphorylation of endogenous proteins. Aliquots $(20 \mu \mathrm{l})$ of the incubates were then blotted onto P81 phosphocellulose paper to separate the phosphorylated substrate from the residual $\left[\gamma_{-}{ }^{32} \mathrm{P}\right]$ ATP. Blots were then immersed in $0.75 \%$ phosphoric acid and washed 10 times with a final wash in acetone and then quantified using scintillation counting. The results indicating protein kinase A activity are expressed as picomoles of substrate-incorporated phosphate per minute per microgram of protein.

In situ hybridization. Preparation and description of riboprobes as well as the in situ hybridization procedure have been described previously (Donaldson et al., 1995). Briefly, sections were post-fixed in $4 \%$ paraformaldehyde (in $0.1 \mathrm{~m}$ phosphate buffer, $\mathrm{pH} 7.4$ ), washed in three changes of $2 \times \mathrm{SSC}(0.3 \mathrm{M} \mathrm{NaCl}, 0.03 \mathrm{M}$ sodium citrate) in sterile water containing $0.2 \%$ diethylpyrocarbonate, and hybridized using $\left[{ }^{35} \mathrm{~S}\right] \mathrm{UTP}$-labeled cRNA antisense probes for either AP-2 or NGFI-A mRNA. The AP-2 probe was transcribed from a plasmid containing a 240 bp BamHI cDNA fragment cloned into Bluescript SK ${ }^{+}$vector (Mitchell et al., 1991). The NGFI-A probe was transcribed from a plasmid containing a $441 \mathrm{bp}$ EcoRI cDNA fragment cloned into an Bluescript KS vector. The NGFI-B probe was transcribed from a plasmid containing a $450 \mathrm{bp}$ SmaI1 cDNA fragment cloned into Bluescript KS. The cFOS probe was tran- 
scribed from a plasmid containing a $2.0 \mathrm{~kb}$ EcoRI cDNA fragment cloned into a Bluescript $\mathrm{SK}^{+}$vector (Morgan and Curran, 1991). The cJUN probe was transcribed from a plasmid containing a $700 \mathrm{bp} E c o$ RI cDNA fragment cloned into a Bluescript $\mathrm{SK}^{+}$vector. The probes were transcribed using either T7 (NGFI-A, NGFI-B, cJUN, cFOS) or T3 RNA polymerases. Probes were denatured by heating at $70^{\circ} \mathrm{C}$ and added to hybridization buffer $(50 \%$ deionized formamide, $600 \mathrm{~mm} \mathrm{NaCl}, 10 \mathrm{~mm}$ Tris, pH 7.5, $1 \mathrm{~mm}$ EDTA, $0.02 \%$ Ficoll, $0.02 \%$ polyvinylpyrrolidone, $0.1 \%$ bovine serum albumin, $100 \mu \mathrm{g} / \mathrm{ml}$ denatured salmon sperm DNA, $50 \mu \mathrm{g} / \mathrm{ml}$ yeast tRNA, $10 \%$ dextran sulfate, and $15 \times 10^{7} \mathrm{cpm} / \mathrm{ml}$ of $\left[{ }^{35}\right.$ S]UTP-labeled cRNA antisense probe. Hybridization mix $(100 \mu \mathrm{l})$ was added to each section and hybridized for $18 \mathrm{hr}$ at $55^{\circ} \mathrm{C}$ in sealed humid chambers. Control sections were hybridized under identical conditions with similarly labeled "sense" RNA. After hybridization, slides were rinsed in $2 \times \mathrm{SSC}$ and treated with RNase A $(30 \mu \mathrm{g} / \mathrm{ml})$ for $60 \mathrm{~min}$ at $37^{\circ} \mathrm{C}$. Slides were then washed in decreasing salt concentrations to a final stringency of $0.1 \times \mathrm{SSC}$ (containing $14 \mathrm{~mm} \beta$-mercaptoethanol) at $50^{\circ} \mathrm{C}$. Sections were dehydrated in increasing concentrations of ethanol (in $0.3 \mathrm{M}$ sodium acetate), air-dried, and dipped in photographic emulsion (Kodak, NTB-2) and exposed at $4^{\circ} \mathrm{C}$ for $21 \mathrm{~d}$ before being developed and counterstained with cresyl violet.

The hybridization signal within dorsal hippocampal subregions was quantified by grain counting over individual hippocampal neurons using a light microscope under bright-field illumination by an individual unaware of the group from which the slide was derived. For each cell field, grains over approximately 50 individual neurons/section were counted, and counting was performed on four sections per animal. The cells selected for counting were determined by placing a grid over the cell field in a specified location, and the cells lying closest to the center of the grid were examined. In this way the same region was examined across all sections for all animals.

After subtraction of background, mean values were derived for each hippocampal cell field for each animal. Background was obtained from each section using areas of size similar to counted neurons randomly selected from neuropil. Background ranged between 5 and $15 \%$ of values found over hippocampal cells, and a positive signal was defined as one that was at least $5 \times$ background. These data were analyzed using a one-way ANOVA (treatment) with one repeated measure (hippocampal subfield) with Tukey post hoc tests.

Western blots and immunocytohistochemistry. After rapid decapitation, brains were removed and placed on ice. The hippocampi were dissected, snap frozen on dry ice, and stored at $-80^{\circ} \mathrm{C}$. Frozen samples were placed into a microcentrifuge tube containing $\sim 5 \mathrm{vol}$ of ice-cold homogenization buffer ( $30 \mathrm{~mm}$ Tris, $1 \mathrm{~mm}$ EDTA, $10 \mathrm{~mm}$ sodium molybdate, $10 \% \mathrm{v} / \mathrm{v}$ glycerol, and $1 \mathrm{~mm}$ dithiothreitol (TEDGM; pH adjusted to 7.4 with 1 $\mathrm{mM}$ PMSF and $1 \mu \mathrm{g} / \mathrm{ml}$ aprotinin) and homogenized on ice using a Vibra Cell Sonicator (Sonic and Materials, Danbury, CT) to disrupt tissue and cells. Homogenization was confirmed under light microscopy. The homogenate was centrifuged at $2^{\circ} \mathrm{C}$ for $45 \mathrm{~min}$ at $15,000 \times g$. Supernatant (soluble protein fraction) was collected, and protein content was determined using the method of Bradford (1976) and ranged from 1.5 to 2.5 $\mu \mathrm{g} / \mu \mathrm{l}$.

Protein samples $(25 \mu \mathrm{g})$ were mixed with an equal volume of $2 \times$ sample buffer $(0.25 \mathrm{M}$ Tris- $\mathrm{HCl}, 20 \%$ glycerol, $4 \%$ SDS, $0.005 \%$ bromoethanol blue, and 5\% $\beta$-mercaptoethanol) and subjected to denaturing and reducing electrophoresis on Tris-glycine polyacrylamide gels. Proteins were electrophoretically transferred according to the method of Towbin et al. (1979) onto nitrocellulose membranes (Amersham, Oakville, Ontario) and air-dried overnight. The membranes were blocked for $1 \mathrm{hr}$ at room temperature with 5\% Carnation dried milk $[10 \%$ for cAMP response element binding protein (CREB) and phospho-CREB (p-CREB) studies] in TBS-T (Tris, NaCl, $0.1 \%$ Tween20 , pH 7.6, or $10 \%$ for CREB and p-CREB), washed briefly in TBS-T, and incubated overnight at $4^{\circ} \mathrm{C}$ with commercially available antibodies for either NGFI-A, AP-2 (anti-NGFI-A antibody SC110 or anti-AP-2 antibody SC184, both obtained from Santa Cruz Biotechnology, Santa Cruz CA) CREB, or phospho-CREB (anti-CREB antibody 06-504 or anti-phospho-CREB antibody 06-519 obtained from Upstate Biotechnology) diluted at 1:5000 in TBS-T containing $0.5 \%$ milk. Membranes were washed for $20 \mathrm{~min}$ with TBS-T and incubated with secondary horseradish peroxidase-labeled antibody (anti-rabbit IgG, Amersham) diluted 1:5000 in TBS-T for $1 \mathrm{hr}$ at room temperature. After four $15 \mathrm{~min}$ washes in TBS-T, membranes were then exposed using an ECL kit (Amersham) and apposed to film (ECL Hyperfilm, Amersham). To verify the accuracy of sample loading, membranes were stripped and reprobed with an

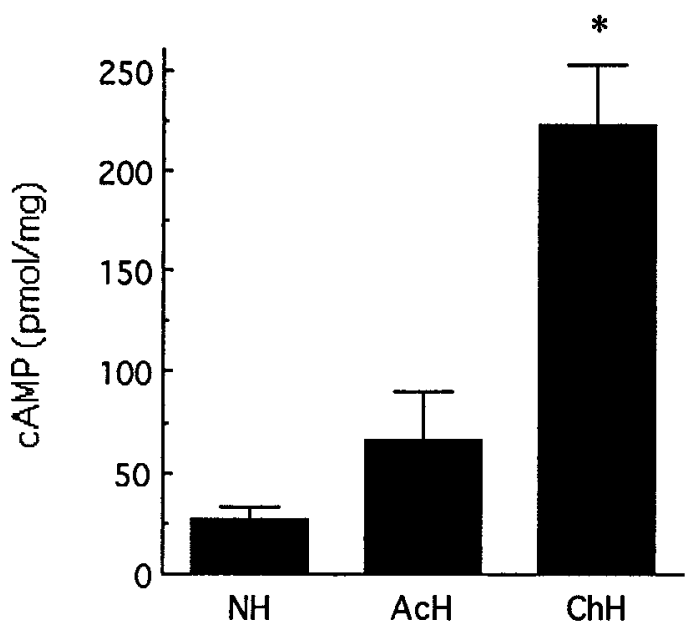

Figure 1. Mean $( \pm$ SEM) level of cAMP in hippocampi from acutely handled $(\mathrm{AcH})$, chronically handled $(\mathrm{ChH})$, and nonhandled $(\mathrm{NH})$ animals. Acutely handled rats were handled only on day 7, whereas chronically handled animals were handled once per day from days 1 to 7 ; animals were killed immediately after handling on day 7 . $\mathrm{NH}$ animals were killed immediately after removal from the home cage. ${ }^{*} p<0.001, n=7-9$ per group.

$\alpha$-tubulin monoclonal antibody (Biodesign International, Kennebunkport, ME) diluted at 1:5000. Optical density readings for the AP-2 (49.5 $\mathrm{kDa})$ or NGFI-A $(88 \mathrm{kDa})$ bands were determined using a computerassisted densitometry system (MCID Systems).

Immunocytohistochemistry was performed on frozen sections prepared from brains that were removed and frozen immediately in isopentane cooled to $-70^{\circ} \mathrm{C}$. Coronal sections $20 \mu \mathrm{m}$ thick were cut using a cryostat and stored at $-80^{\circ} \mathrm{C}$ until analyzed. Frozen tissue sections were fixed in $4 \%$ paraformaldehyde for $15 \mathrm{~min}$ and then incubated in a $3 \%$ hydrogen peroxide/methanol solution $(15 \mathrm{~min})$ to quench potential endogenous peroxidase activity. Sections were washed $2 \times 10$ min each with $0.1 \mathrm{M}$ PBS containing $0.3 \%$ Triton $\mathrm{X}-100$ and sodium azide and then incubated with primary antibody (anti-NGFI-A SC110 or anti-AP-2 SC184; Santa Cruz Biotechnology) at 1:2500 dilutions for NGFI-A or AP-2 and 1:5000 dilutions for CREB and p-CREB overnight at $4^{\circ} \mathrm{C}$ (antibody buffer consisted of $0.1 \mathrm{M}$ PBS, 3\% normal goat serum and sodium azide). The sections were then washed $3 \times 15$ min with PBS, incubated overnight with biotinylated goat anti-rabbit antiserum in PBS with $3 \%$ NGS and $0.3 \%$ Triton $\mathrm{X}-100$ at $4^{\circ} \mathrm{C}$, washed $3 \times 15 \mathrm{~min}$ in PBS, and incubated with an avidin-biotin complex (Vectastain ABC Elite Kit) for $1 \mathrm{hr}$ at room temperature. Sections were again washed in PBS and

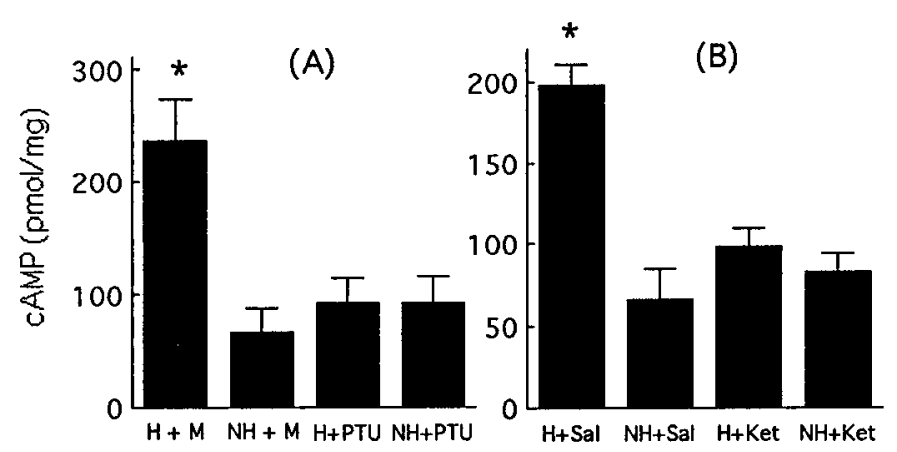

Figure 2. A, Mean ( \pm SEM) level of cAMP in hippocampi from chronically handled $(H)$ and nonhandled $(N H)$ animals treated with either propylthiouracil $(P T U)$ or saline $(S a l)$ vehicle. ${ }^{*} p<0.01, n=7-8$ per group. $B$, Mean $( \pm \mathrm{SEM})$ level of cAMP in hippocampi from chronically handled $(H)$ and nonhandled $(N H)$ animals treated with either ketanserin $(K e t)$ or saline vehicle. ${ }^{*} p<0.01, n=7-8$ per group. For both studies, animals were killed immediately after handling on day $7(H)$ or after removal from the home cage $(\mathrm{NH})$. 


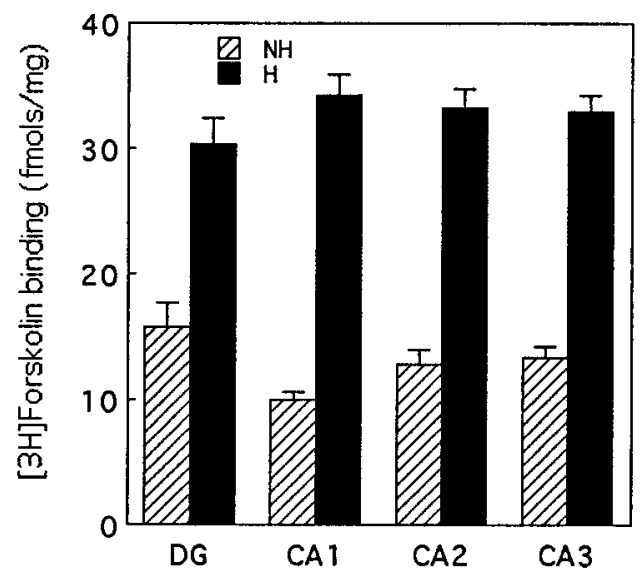

Figure 3. Mean ( \pm SEM) levels of specific $\left[{ }^{3} \mathrm{H}\right]$ forskolin binding (femtomol/milligram) in various hippocampal cell fields in chronically handled $(H)$ and nonhandled $(\mathrm{NH})$ animals killed immediately after handling on day $7(H)$ or after removal from the home cage $(\mathrm{NH})$. All $H$ versus $N H$ comparisons are significant at $p<0.001, n=10-12$ per group.

then treated with diaminobenzidine tetrachloride (DAB) in phosphate buffer containing hydrogen peroxide for 3-10 min. After visualization, sections were rinsed, left to dry overnight, dehydrated in a graded series of ethanol, immersed in xylene, and coverslipped.

\section{RESULTS}

\section{Effects of handling on hippocampal camp levels:} thyroid hormone and 5- $\mathrm{HT}$ mediation

Our first question was whether handling induced changes in hippocampal cAMP levels and whether such changes might be dependent on the activation of thyroid hormones and ascending serotonergic activity. We examined in vivo changes in hippocampal cAMP levels in animals exposed to either acute (handling only on day 7 of life) or chronic (handling on each of days 1-7) handling. In all cases animals were killed immediately after the 15 min period of handling on day 7 of life. Handling produced only a small increase in cAMP levels in acutely handled animals (Fig. 1). In contrast, in animals handled on each of the first $7 \mathrm{~d}$ of life, handling produced a highly significant $(p<0.0001)$ almost 10 fold increase in hippocampal cAMP levels (Fig. 1). These data

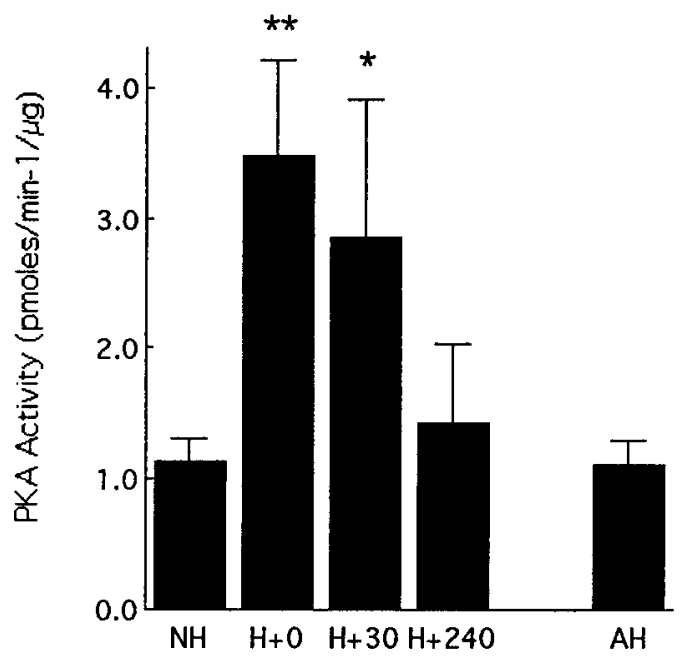

Figure 4. Mean ( \pm SEM) level of hippocampal protein kinase A activity in nonhandled $(N H)$, acutely handled $(A H)$, and chronically handled $(H)$ animals killed at various times after handling on day 7 . AH animals were killed immediately after handling on day $7 .{ }^{* *} p<0.01$, ${ }^{*} p<0.05, n=5-7$ per group.

indicate the potent effect of handling on in vivo hippocampal cAMP levels and suggest that some form of "sensitization" to the handling occurs over the first week of life.

We then examined the effects of either PTU (Meaney et al., 1987), a thyroid hormone synthesis inhibitor, or ketanserin, a 5- $\mathrm{HT}_{2}$ receptor antagonist (Mitchell et al., 1990a), on handlinginduced changes in hippocampal cAMP levels. As seen in Figure $2 A$, handling produced a significant increase $(p<0.001)$ in hippocampal cAMP levels. This effect was completely blocked with concurrent PTU administration. Note that PTU treatment alone had no effect on hippocampal cAMP levels (Fig. $2 A$, compare $\mathrm{NH}+$ mash control vs $\mathrm{NH}+$ PTU). Likewise, concurrent treatment with ketanserin blocked the handling-induced increase in hippocampal cAMP levels (Fig. 2B). Again, there was no effect of ketanserin treatment alone on hippocampal cAMP levels (Fig. $2 \mathrm{~B}$, compare $\mathrm{NH}+$ saline control vs $\mathrm{NH}+$ ketanserin). The absence of PTU or ketanserin effects on unstimulated

\section{NGFI-A mRNA}

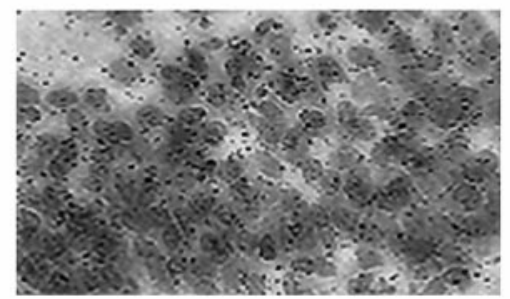

Non-Handled

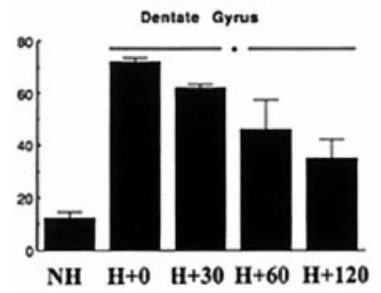

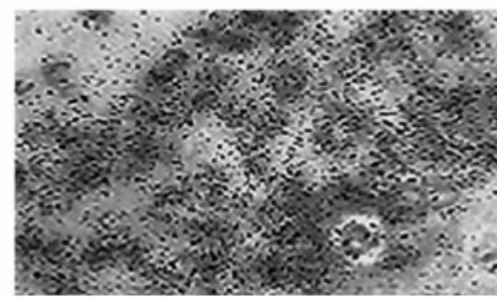

Handled

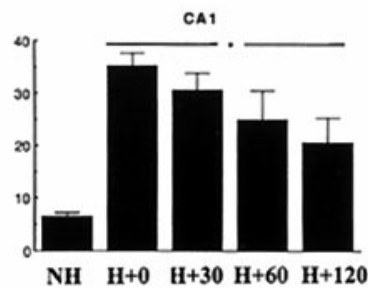

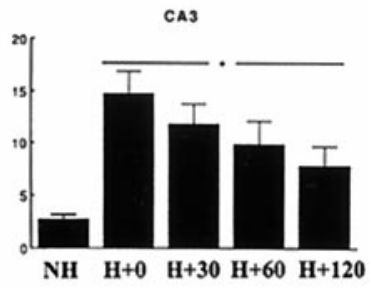

Figure 5. Mean ( \pm SEM) grains per cell as a function of the area of the cell for NGFI-A mRNA in situ hybridization in various hippocampal regions from nonhandled $(\mathrm{NH})$ and chronically handled $(H)$ animals killed at various times (in minutes) after handling on day 7. For all regions, each handling time point is significantly different from the NH group at $p<0.01(n=3-4$ per group). The inset provides a representative photomicrograph of grains over Nissl-stained neurons in the CA1 region of Ammon's horn. 


\section{AP-2 mRNA}

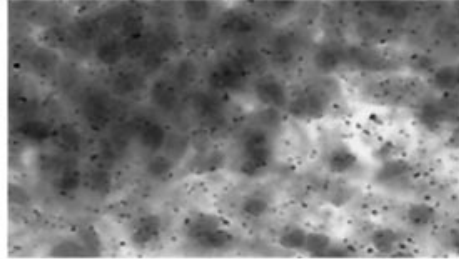

Non-Handled

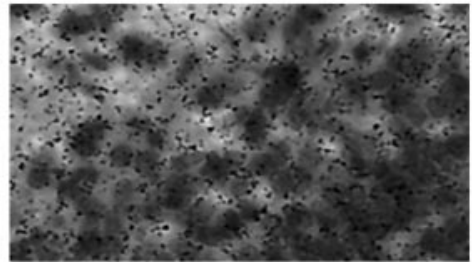

Handled
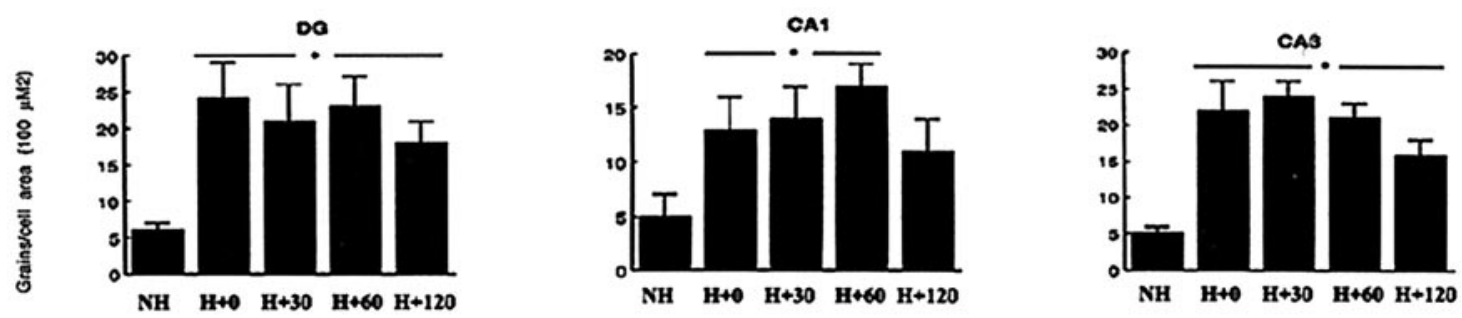

Figure 6. Mean $( \pm$ SEM) grains per cell as a function of the area of the cell for the AP-2 mRNA in situ hybridization in various hippocampal regions from nonhandled $(\mathrm{NH})$ and chronically handled $(H)$ animals killed at various times points (in minutes) after handling on day 7 . For all regions, each handling time point is significantly different from the NH group at $p<0.05$ ( $n=3-4$ per group). The inset provides a representative photomicrograph of grains over Nissl-stained neurons in the CA1 region of Ammon's horn.

Table 1. Mean ( \pm SEM) grains/cell as a function of the area $\left(100 \mu \mathrm{m}^{2}\right)$ of the cell for the AP-2 mRNA and NGFI-A mRNA in situ hybridization in various brain regions from nonhandled and chronically handled animals killed at $\mathbf{3 0} \mathrm{min}$ after handling on day 7

\begin{tabular}{llllll} 
& \multicolumn{2}{l}{ NGFI-A mRNA levels } & & & AP-2 mRNA levels \\
\cline { 2 - 3 } \cline { 5 - 6 } Brain Region & Handled & Nonhandled & & Handled & Nonhandled \\
\hline Amygdala & $3.4 \pm 0.2$ & $1.9 \pm 1.0$ & & $3.1 \pm 0.4$ & $3.9 \pm 1.0$ \\
Hypothalamus & $3.5 \pm 0.4$ & $3.1 \pm 0.3$ & & $3.9 \pm 0.4$ & $2.4 \pm 0.2$ \\
Cortex & $2.3 \pm 0.3$ & $1.9 \pm 0.2$ & & $3.6 \pm 0.4$ & $2.3 \pm 1.1$ \\
\hline
\end{tabular}

hippocampal cAMP levels is consistent with the idea that these systems mediate handling-induced effects on cAMP formation.

\section{The effect of handling on the activation of adenylyl cyclase}

$\left[{ }^{3} \mathrm{H}\right]$ forskolin autoradiography was used to examine adenylyl cyclase in hippocampal sections from handled and nonhandled rat pups killed immediately after handling or directly from the home cage at $7 \mathrm{~d}$ of age. $\left[{ }^{3} \mathrm{H}\right]$ forskolin binding is thought to reflect an activated form of adenylyl cyclase (Seamon et al., 1984; Worley et al., 1986). The use of autoradiography allowed us to examine the anatomical distribution of the handling effect on cAMP levels in terms of cyclase activation in specific hippocampal cell fields.

$\left[{ }^{3} \mathrm{H}\right]$ forskolin binding was significantly elevated after handling in all hippocampal cell fields (Fig. 3). The magnitude of the handling effect was largely the same in each area, although baseline $\left[{ }^{3} \mathrm{H}\right]$ forskolin binding levels in nonhandled rats were slightly higher in the dentate gyrus. These findings suggest that the increase in adenylyl cyclase-cAMP occurs across all areas of the dorsal hippocampus.

The effects of handling on hippocampal protein kinase A activity

Handling produced a marked increase in protein kinase A activity (Fig. 4). The handling effect on hippocampal protein kinase A activity paralleled the effects on cAMP and thus was apparent only in animals that were handled on each of the preceding $7 \mathrm{~d}$; acute handling on day 7 had no effect on protein kinase A activity (Figs. 1, 4). Among the chronically handled animals, handling on day 7 of life produced a significant increase in protein kinase A activity in hippocampus that was apparent at $0 \min (p<0.01)$ and $30 \mathrm{~min}(p<0.05)$ after the end of the handling session (Fig. 4). This effect on protein kinase A activity was no longer evident by $240 \mathrm{~min}$ after handling.

\section{Effects of handling on the expression of cAMP-inducible transcription factors}

We then examined the effect of handling on hippocampal mRNA expression for a number of cAMP-inducible transcription factors, including AP-2, NGFI-A, NGFI-B, cJUN, and cFOS in chronically handled animals using in situ hybridization. Animals were exposed to handling on each of days 1-7 of life and were killed at various times after the final handling session. Grain counting was performed over individual hippocampal cells (see Materials and Methods). Note that we found no differences between handled and nonhandled rats in hippocampal neuron number or in cell body diameter [also see Meaney et al. (1988)]; the data were nevertheless expressed as grain counts per cell body area (McCabe et al., 1989).

In all cases, constitutive transcription factor expression was detectable but low (i.e., two to three times background). There was no effect of handling on the levels of mRNAs for NGFI-B, cJUN, or cFOS (data not shown). In contrast, handling produced a highly significant increase in NGFI-A mRNA expression that was apparent in each of the hippocampal cell fields (Fig. 5). Significant $(p<0.001)$ increases in NGFI-A mRNA expression were apparent as early as the $\mathrm{H}+0$ min time point (i.e., immediately after the $15 \mathrm{~min}$ handling period). The effect was diminished somewhat at $\mathrm{H}+120$ min but remained significant $(p<0.05)$. Analysis of the grain-count data revealed that the effect was widely distributed throughout the dorsal hippocampus. 

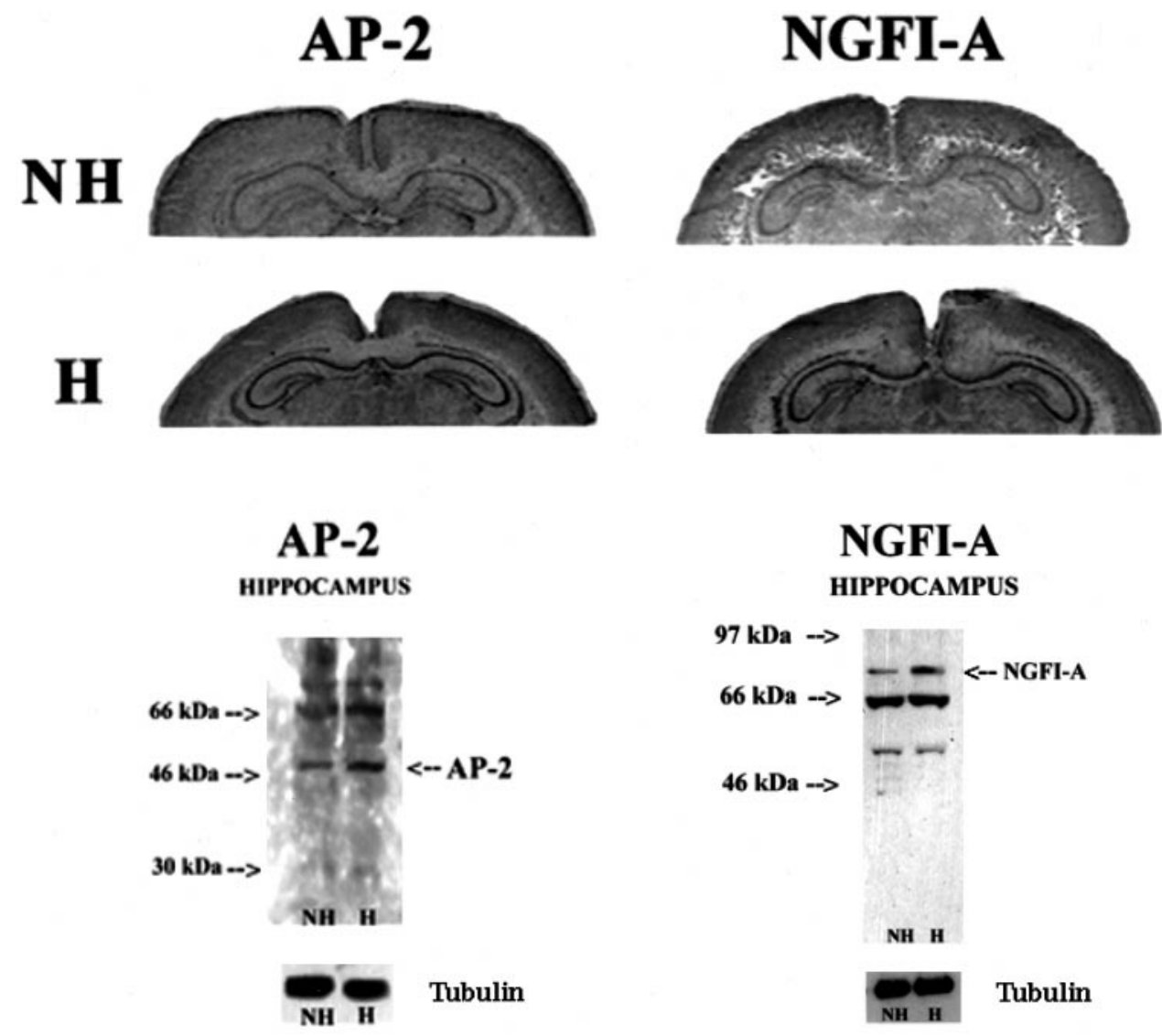

Handling served to increase NGFI-A mRNA expression across the entire hippocampus rather than in a small subset of cells (also see Fig. 5, inset). This finding was apparent in the general shift in the distribution of grain counts toward higher grain density (data not shown).

Handling also increased AP-2 mRNA expression in all hippocampal cell fields (Fig. 6); however, the effect was less marked than that for NGFI-A mRNA. In each cell field the increase in AP-2 was significant and represented a two- to fourfold increase in mRNA levels by comparison to nonhandled controls. The analysis of the frequency distribution (data not shown) suggested that the effect on AP-2 mRNA was somewhat less uniform than that for NGFI-A mRNA expression, but the distribution was nevertheless maintained and shifted toward higher grain counts.

We also examined the tissue specificity for the effect of handling on both NGFI-A and AP-2 expression in amygdala (sampling included the lateral, medial, basolateral, and central nuclei), the paraventricular nucleus of the hypothalamus, and the somatosensory cortex. In these regions, unlike the hippocampus, handling had no effect on glucocorticoid receptor expression. Handling had no effect on either NGFI-A or AP-2 mRNA levels in any of these regions (Table 1).

We also examined the distribution of the handling effects on hippocampal cells using immunocytohistochemical staining for NGFI-A and AP-2 in hippocampal sections from day 7 animals. There were low levels of NGFI-A and AP-2 immunoreactivity visible in hippocampal sections from nonhandled animals. As seen in Figure 7, handling produced a rather uniform and clear increase in both NGFI-A and AP-2 immunoreactivity across all hippocampal cell fields. The results of a detail time course study (data not shown) showed that NGFI-A and AP-2 immunoreac-

\section{NGFI-A HIPPOCAMPUS}

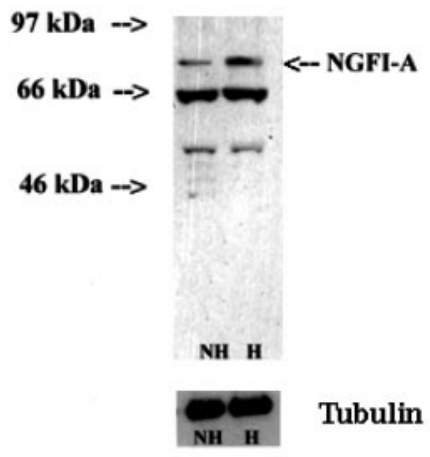

tivity increased maximally $60-120 \mathrm{~min}$ after handling and remained elevated for at least $240 \mathrm{~min}$.

To better quantify such changes, we examined the effect of handling on NGFI-A and AP-2 expression using Western blotting. We also examined whether such changes in NGFI-A and AP-2 expression might be blocked by concurrent treatment with either PTU or ketanserin. In each case, handling produced a significant increase in NGFI-A and AP-2 immunoreactivity (Fig. $8 A, B)$. Concurrent treatment with PTU blocked the effect of handling on both NGFI-A and AP-2 (Fig. $8 A$ ). Likewise, ketanserin treatment blocked the handling-induced increase in both NGFI-A and AP-2 (Fig. 8B). These findings parallel the effects of these treatments on handling-induced changes in cAMP levels (compare Figs. 2, 8).

\section{The effect of handling on hippocampal CREB and phospho-CREB-like immunoreactivity}

The effect of handling on the expression and activation of CREB was studied using antibodies for either CREB or phospho-CREB. Handling had no effect on CREB-like immunoreactivity using either Western blotting (Fig. 9A) or immunocytohistochemistry (data not shown). Likewise, there was no effect of handling on phospho-CREB-like immunoreactivity (Fig. 9B, C). In both cases, constitutive levels of these factors (i.e., those observed in nonhandled controls) were extremely high and greatly exceeded those observed in hippocampal tissue from adult animals (data not shown).

\section{DISCUSSION}

In the current studies we examined the cellular and molecular events that might underlie the effect of postnatal handling on 

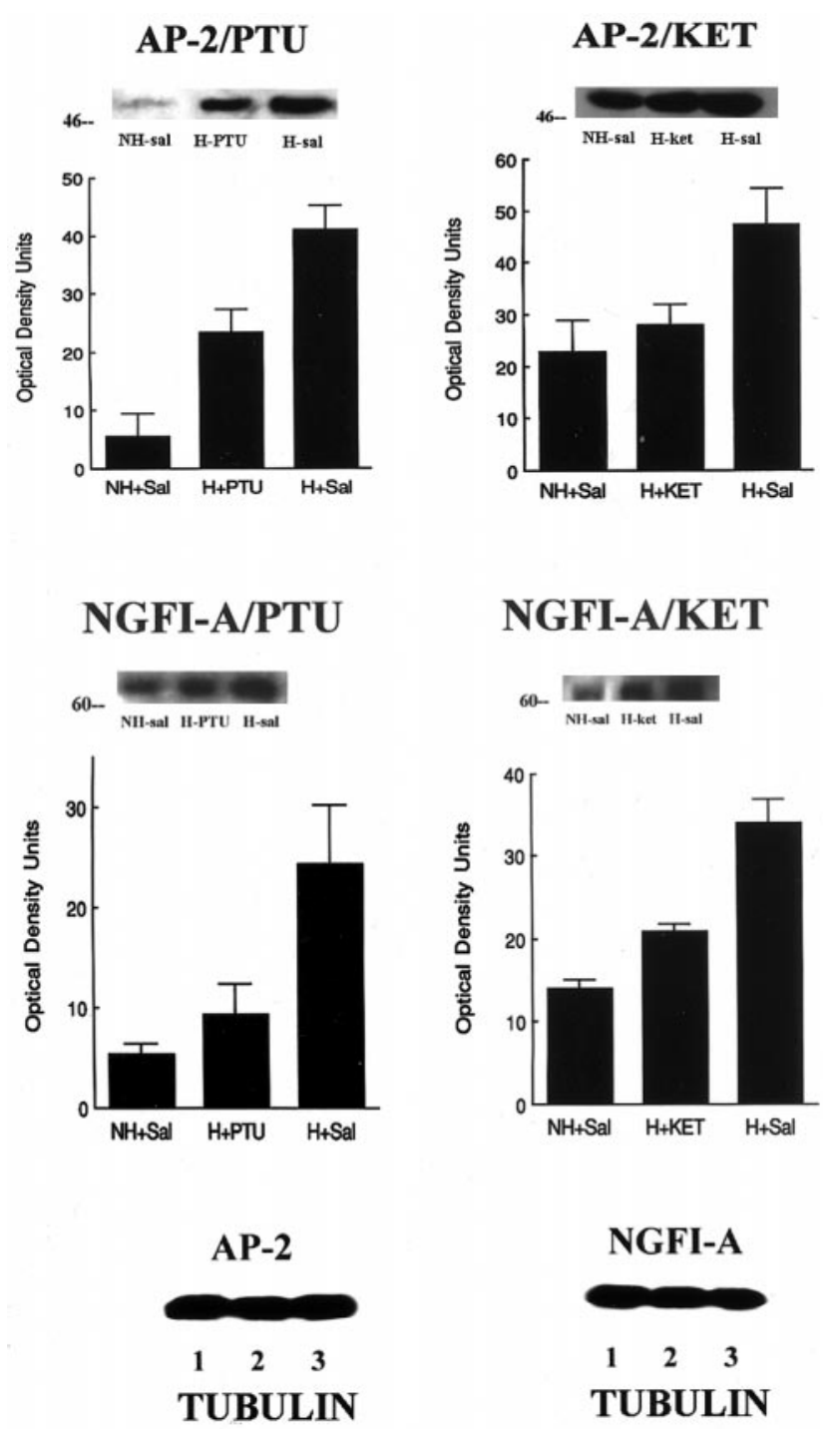

Figure 8. Western immunoblot analysis of NGFI-A- and AP-2-like immunoreactivity (measures are derived from 3-4 blots per group, each from tissue from separate animals) with antibodies to either NGFI-A or AP-2, which detects the $88 \mathrm{kDa}$ NGFI-A band or the $49.5 \mathrm{kDa}$ AP- 2 band. Twenty-five micrograms of protein were loaded from hippocampal homogenates from chronically handled $(H)$ and nonhandled $(N H)$ animals killed immediately after handling on day 7 of life. Representative blots are shown for each study. A, Animals were treated with PTU, a thyroid synthesis inhibitor, or saline for days 1-7 of life. Handling produced a significant $(p<0.001)$ increase in both NGFI-A and AP-2 expression. Treatment with PTU significantly reduced NGFI-A and AP-2 expression in chronically handled rats $(H+P T U$ vs $H+S a l, p<0.01$ for both transcription factors). $B$, Animals were treated with ketanserin $(2 \mu \mathrm{g} / \mathrm{g}$ body weight), a 5-HT receptor blocker, or saline for days 1-7 of life. Handling produced a significant $(p<0.001)$ increase in both NGFI-A and AP-2 expression in hippocampus. Treatment with ketanserin significantly reduced NGFI-A and AP-2 expression in chronically handled rats $(H+P T U$ vs $H+$ Sal, $p<0.01$ for both transcription factors). $C$, To correct for potential loading errors, all blots were stripped and reprobed for $\alpha$-tubulin staining. Shown here are representative blots for the AP-2 and NGFI-A studies. For each study, the data are derived from four to five independent experiments.

hippocampal glucocorticoid receptor gene expression. Postnatal handling permanently increases hippocampal glucocorticoid receptor gene expression (O'Donnell et al., 1994). This effect occurs during the first week of life (Meaney and Aitken, 1985) and is dependent on increases in pituitary-thyroid activity and ascending 5-HT systems (Meaney et al., 1987; Mitchell et al., 1990b; Smythe et al., 1994). In vitro studies with primary cultures of hippocampal neurons indicate that 5-HT can directly increase glucocorticoid receptor levels and that this effect is mediated by increased cAMP formation and activation of protein kinase A activity (Mitchell et al., 1990b, 1992). In the in vivo studies reported here, handling during the first week of life increased hippocampal cAMP levels, protein kinase A activity, and the expression of certain cAMP-inducible transcription factors. The effect of handling on hippocampal cAMP levels was completely blocked by either the thyroid hormone synthesis inhibitor PTU or the 5-HT receptor antagonist ketanserin. Both treatments have been previously reported to block the effects of handling on hippocampal glucocorticoid receptor expression (Meaney et al., 1987; Mitchell et al., 1990b). These findings are consistent with the idea that the handling effect on hippocampal cAMP levels mediates the effect on glucocorticoid receptor expression.

Across a wide range of serotonergic compounds there is a strong correlation $(+0.97)$ between the effect on cAMP levels and that on glucocorticoid receptor levels in cultured hippocampal neurons (Meaney et al., 1994; Weaver and Meaney, 1997). We found that 5-HT, as one might expect, increases AP-2 and NGFI-A expression in cultured hippocampal neurons, and the effect is blocked by the protein kinase A inhibitor H8 (Laplante, 1996). These results are consistent with in vivo findings showing that both thyroid hormones (Mellstrom et al., 1994) and 5-HT (Humblodt et al., 1997) regulate neuronal NGFI-A expression. In cultured hippocampal neurons, the effect of 5-HT on AP-2 and NGFI-A expression, as well as the effect on glucocorticoid receptor levels, is mimicked by the high-affinity $5-\mathrm{HT}_{7}$ receptor agonist 5-CT. These effects are blocked by either ritanserin or ketanserin but not by pindolol, a pharmacological profile that is consistent with a 5- $\mathrm{HT}_{7}$ receptor (Lovenberg et al., 1993; Shen et al., 1993; Plassat et al., 1994; Tsou et al., 1994). The 5- $\mathrm{HT}_{7}$ receptor is directly and positively coupled to cAMP (Lovenberg et al., 1993; Shen et al., 1993; Plassat et al., 1994; Tsou et al., 1994), and there is considerable $5-\mathrm{HT}_{7}$ receptor mRNA expression in the rat dorsal hippocampus in both adults (Lovenberg et al., 1993; Tsou et al., 1994) and neonates (Laplante, 1996). Taken together, these findings suggest that the serotonergic regulation of glucocorticoid receptor expression in hippocampal neurons is mediated through a $5-\mathrm{HT}_{7}$ receptor.

Interestingly, there was a clear distinction between the effects of acute (day 7 only) and chronic (days 1-7) handling on both cAMP and PKA activation. In both cases the effect was apparent only under chronic handling conditions. These findings parallel the results of earlier studies on the activation of ascending 5-HT systems. Chronic handling has a significantly greater effect on 5-HT turnover in the hippocampus than does acute handling (Smythe et al., 1994), and these results suggest that something like a sensitization effect occurs with repeated handling. Nevertheless, handling does not appear to produce any short- or long-term effects on 5-HT innervation to the dorsal hippocampus. Handled and nonhandled rats do not differ in hippocampal levels of $\left[{ }^{3} \mathrm{H}\right]$ paroxetine binding or 5-HT-like immunoreactivity at either 7 or $90 \mathrm{~d}$ of age (S. Sharma and M. J. Meaney, unpublished observations). Moreover, handling has no effect on hippocampal 5- $\mathrm{HT}_{7}$ receptor mRNA levels in day 7 rats (Laplante, 1996). Thus, the basis for this sensitization-like effect remains unclear. However, it is interesting that increased NGFI-A expression has been associated with increases in synaptogenesis after environmental enrich- 


\section{Phosphorylated CREB}

CREB

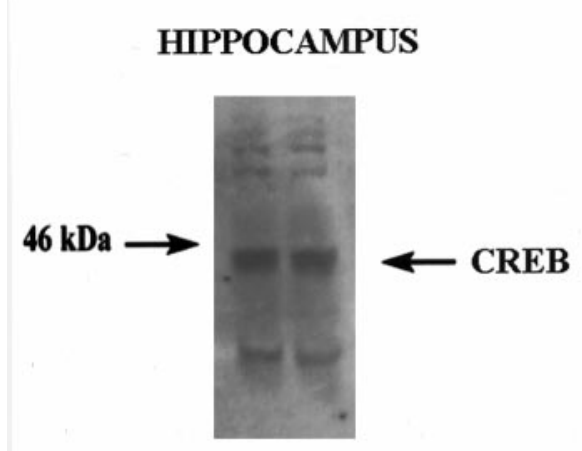

H NH

\section{HIPPOCAMPUS}

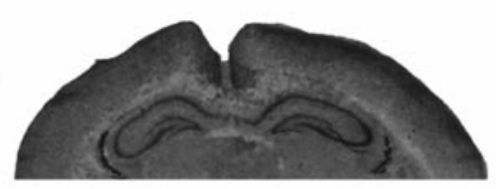

Non-Handled

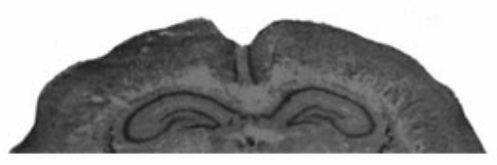

Handled
PCREB

\section{HIPPOCAMPUS}

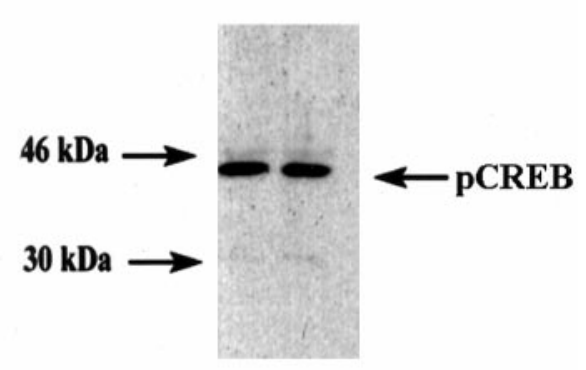

H NH

Figure 9. Left, Representative Western immunoblot analysis of CREB-like immunoreactivity in hippocampal samples from chronically handled ( $H$ ) and nonhandled $(\mathrm{NH})$ animals on day 7 of life. Middle, Representative results of immunocytohistochemical studies of phospho-CREB-like immunoreactivity in dorsal hippocampus of chronically handled and nonhandled animals on day 7 of life. Handled animals were killed 60 min after handling. Note the rather high and uniform levels of staining throughout the hippocampus in both groups of animals. Right, Representative Western blot analysis of phospho-CREB-like immunoreactivity with an antibody that detects the $44 \mathrm{kDa}$ phospho-CREB band in hippocampal samples from chronically handled $(H)$ and nonhandled $(\mathrm{NH})$ animals on day 7 of life.

ment (Wallace et al., 1996). It is possible that handling induces some local synaptic alterations in the hippocampus that could ultimately mediate increased 5-HT release in response to subsequent episodes of handling.

Alterations in cAMP levels are known to affect gene transcription. This effect is apparently mediated by activation of cyclic nucleotide-dependent protein kinases and a number of transcription factors (Habener, 1990). Postnatal handling significantly increased hippocampal protein kinase A activity, an effect that endured for at least $30 \mathrm{~min}$ beyond the period of handling. The increase in protein kinase A activity was accompanied by increased mRNA expression for NGFI-A and AP-2. AP-2 and NGFI-A expression and activity have been shown to be enhanced by cAMP (Imagawa et al., 1987; Philipp et al., 1994; Garcia et al., 1999). The increase in mRNA levels was apparent immediately after the period of handling and was evident in all hippocampal cell fields. Finally, the handling effect was specific for AP-2 and NGFI-A; handling had no effect on cFOS, cJUN or NGFI-B mRNA expression. The absence of a handling-induced changes in the expression of AP-1 proteins, cFOS, or cJUN may reflect a certain immaturity in the signaling pathways that serves to activate these immediate early genes. Jung et al. (1998) found that electroconvulsive shock increased hippocampal NGFI-A expression on postnatal day 7 , whereas cFOS levels were unaffected until day 14 of life (Pennypacker et al., 1994). Interestingly, although we found robust effects of handling on hippocampal cAMP levels, there are no such effects on inositol phosphate levels in day 7 pups (Parent et al., 1996). In vitro, the application of 5-HT increases cAMP levels in cultured hippocampal neurons (see Mitchell et al., 1992), but does not affect IP metabolism (Parent et al., 1996). Thus, the specificity of the handling effect could reflect, in part, the status of the cellular signaling pathways during the first week of life.

There was no effect of handling on hippocampal levels of either CREB or phospho-CREB. Although this may appear surprising considering the magnitude of the handling-induced increase in hippocampal cAMP, it is apparent that constitutive expression of

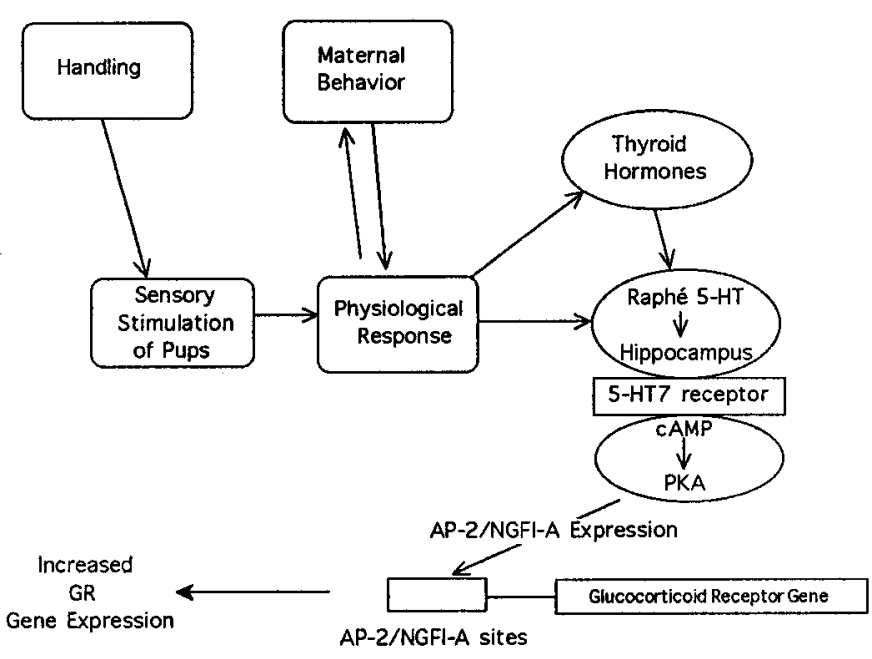

Figure 10. Handling provides for multisensoral stimulation of pups, which leads to various changes in pup physiology and thus in the sensory characteristics of the pups. This, in turn, leads to changes in maternal behavior (Liu et al., 1997; Francis et al., 1999) that appear to mediate the handling effect on hippocampal glucocorticoid receptor gene expression. In response to the handling manipulation, there occurs an increase in circulating levels of triiodothyronine that stimulates 5-HT activity at the level of the hippocampus (see introductory remarks). The increase in both thyroid hormones and 5-HT are obligatory for the handling effect on hippocampal glucocorticoid receptor expression. In vitro studies with cultured hippocampal neurons reveal that 5 -HT can directly modulate glucocorticoid receptor expression in hippocampal neurons and that this effect is mediated by a $5-\mathrm{HT}_{7}$-like receptor, which is positively coupled to cAMP. The results of the current studies show that handling increases hippocampal cAMP formation, PKA activity, and mRNA levels for AP-2 and NGFI-A. Recent studies (Diorio et al., 1997) show that handling also increases AP-2 and NGFI-A binding to their respective consensus sequences, such as those found on a promoter for the human glucocorticoid receptor gene. We propose that these steps are involved in the molecular basis of the handling effect on hippocampal glucocorticoid receptor gene expression. 
both CREB and phospho-CREB are high during the first week of life. Interestingly, CREB expression in cortical neurons in adult animals appears to define activity-dependent plasticity through permissive actions (Frank and Greenberg, 1994; Martin and Kandel, 1996). It may be that during periods of heightened plasticity, especially in regions undergoing rapid cell division and differentiation such as the hippocampus, CREB is necessarily overexpressed by comparison with later life.

Handling also produced an increase in NGFI-A and AP-2 immunoreactivity in all hippocampal cell fields. Both effects were greatly reduced or completely eliminated by pretreatment with either PTU or ketanserin, parallel to the effects of these manipulations in blocking the effect of handling on hippocampal glucocorticoid receptor expression. Interestingly, thyroid hormones have been found to increase NGFI-A mRNA expression in the hippocampus (Pipaon et al., 1992), and this effect appears to be directly mediated by a thyroid receptor response element (Ghorbel et al., 1999). Moreover, the thyroid hormone effect occurs only during the first 2 weeks of life (Mellstrom et al., 1994), a period that corresponds precisely to the known critical period for the effect of postnatal handling on hippocampal glucocorticoid receptor expression (Meaney and Aitken, 1985). Importantly, in the current studies we found that handling had no effect on NGFI-A or AP-2 mRNA expression in the amygdala, hypothalamus, or somatosensory cortex, regions where unlike the hippocampus, glucocorticoid receptor expression is unaltered by handling (Meaney et al., 1996).

Nobukuni et al. (1995) have shown that AP-2 binds to sites on a promoter for the human glucocorticoid receptor and elicits transactivation of promoter activity. Moreover, across a number of cell lines, levels of AP-2 expression were correlated with glucocorticoid receptor promoter activity. On the basis of the positive regulatory effect on glucocorticoid receptor gene transcription, Nobukuni et al., (1995), suggested that AP-2 could, in part, determine glucocorticoid receptor expression during development. Nobukuni et al. (1995) also identified the relevant promoter site (FP7) on the human glucocorticoid receptor gene for AP-2 transactivation. Interestingly this site contains consensus binding sequences for both NGFI-A and AP-2. In recent gelmobility shift studies we showed that handling significantly increased AP-2 and NGFI-A binding to these sequences in hippocampal tissue from day 7 pups (Diorio et al., 1997). Recent findings have also suggested a relationship between NGFI-A and glucocorticoid receptor expression during development. Environmental enrichment increases the hippocampal expression of the mRNAs for NGFI-A (Wallace et al., 1996) and the glucocorticoid receptor (Mohammed et al., 1993). Together, these findings are consistent with the idea that the postnatal handling-induced changes in hippocampal AP-2 and NGFI-A expression could serve to mediate the increase in glucocorticoid receptor gene expression (Fig. 10). Interestingly, AP-2 and NGFI-A have been shown to act synergistically in the regulation of phenylethanolamine $N$-methyltransferase gene expression (Wong et al., 1998).

Early postnatal handling increases glucocorticoid receptor gene expression in forebrain neurons. Two aspects of this programming effect are critical. First, the effect is specific. Postnatal handling increases glucocorticoid but not mineralocorticoid mRNA expression in hippocampal neurons (Sarrieau et al., 1988; O'Donnell et al., 1994). The same is true for the effects of 5-HT on primary hippocampal cell cultures (Mitchell et al., 1990b, 1992). Thus, despite the close homology between the genes encoding for the two receptors, the effect is specific for the glucocor- ticoid receptor. This finding also reflects the fact that handling affects neuronal "differentiation" and not proliferation. Indeed, handling does not directly alter hippocampal neuron density in young adult animals (Meaney et al., 1988). Second, the effects persist for the life of the animal. Thus, as late as 26 months of age, handled rats show increased glucocorticoid receptor levels (Meaney et al., 1988, 1991, 1992). This latter finding underscores what is perhaps the most challenging aspect to this environmental effect: the persistence of the handling effect on hippocampal glucocorticoid receptor levels. What sustains this effect throughout the life of the animal? Interestingly, the 5-HT-induced increase in glucocorticoid receptor levels on cultured hippocampal neurons persists after 5-HT removal from the medium. We have studied these cultures for as long as $4-5$ weeks after the removal of 5-HT from the medium with no decrease in the magnitude of the 5-HT effect (Meaney et al., 1994). Thus, the effect of 5-HT on glucocorticoid receptor density observed in hippocampal culture cells mimics the long-term effects of early environmental events and provides what we believe is an exciting model for the study of environmental regulation of neuronal development.

\section{REFERENCES}

Bradford MM (1976) A Rapid and sensitive method for the quantitation of microgram quantities of protein utilizing the principle of protein-dye binding. Biochemistry 72:248-254.

Brindley DN, Rolland Y (1989) Possible connections between stress, diabetes, obesity, hypertension and altered lipoprotein metabolism that may result in atherosclerosis. Clin Sci 77:453-461.

Brown BL, Albano JDM, Ekins RP, Sgherzi AM (1971) A simple and sensitive saturation assay method for the measurement of adenosine 3'5'-cyclic monophosphate. Biochem J 121:561-562.

de Kloet ER, Vregdenhil E, Oitzl MS, Joels M (1998) Brain corticosteroid receptor balance in health and disease. Endo Rev 19:269-301.

Diorio J, Weaver SA, Sharma S, Chapman KE, Seckl JR, Meaney MJ (1997) Handling increases hippocampal AP-2 and NGFI-A binding to a glucocorticoid receptor promoter oligonucleotide sequence. Soc Neurosci Abstr 23:1151.

Donaldson L, McQueen D, Seckl J (1995) Induction of transcription factor AP2 mRNA expression in rat primary afferent neurons during acute inflammation. Neurosci Lett 196:181-184.

Francis D, Diorio J, Laplante P, Weaver S, Seckl J, Meaney M (1996) The role of early environmental events in regulating neuroendocrine development: moms, pups, stress and glucocorticoid receptors. Ann NY Acad Sci 794:136-152.

Francis DD, Diorio J, Liu D, Meaney MJ (1999) Nongenomic transmission across generations in maternal behavior and stress responses in the rat. Science 286:1155-1158.

Frank DA, Greenberg ME (1994) CREB: a mediator of long-term memory from mollusks to mammals. Cell 79:5-8.

Garcia MA, Campillos M, Marina A, Vladiviesio F, Vazquez J (1999) Transcription factor AP-2 activity is modulated by protein kinase-A phosphorylation. FEBS Lett 444:27-31.

Gelhert DR, Dawson TM, Yamamura HI, Wansley JK (1985) Quantitative autoradiography of $\left[{ }^{3} \mathrm{H}\right]$ forskolin binding sites in the rat brain. Brain Res 361:351-360.

Ghorbel MT, Steugnet I, Hadj-Sahraoui N, Topilko P, Levi G, Demeneix B (1999) Thyroid hormone effects on Krox-24 transcription in the post-natal mouse brain are developmentally regulated but not related with mitosis. Oncogene 18:917-924.

Habener JF (1990) Cyclic AMP response element binding proteins: a cornucopia of transcription factors. Mol Endocrinol 4:1087-1094.

Herman JP, Cullinan WE (1997) Neurocircuitry of stress: central control of the hypothalamo-pituitary-adrenal axis. Trends Neurosci 20:78-84.

Humblodt M, Esteve N, Burgun C, Aunis D, Zwiller J (1997) 5-Hydroxytryptamine induces ITS8/egr-1 and c-fos expression in PC 12 cells: involvement of tyrosine protein phosphorylation. Eur J Neurosci 9:84-92.

Imagawa M, Chiu R, Karin M (1987) Transcription factor AP-2 mediates induction by two different signal transduction pathways: protein kinase C and cAMP. Cell 51:251-260. 
Jacobson L, Sapolsky RM (1991) The role of the hippocampus in feedback regulation of the hypothalamic-pituitary-adrenal axis. Endocr Rev 12:118-134.

Jung HY, Kang UG, Joo YH, Cho SC, Jeon SH, Park JB, Kim YS (1998) Electroconvulsive shock does not induce c-fos and junB, TIS1 and TIS.zif268, in neonatal rat hippocampus. Dev Brain Res 108:303-306.

LaPlante P, Meaney MJ (1996) Evidence for 5-HT receptor involvement in the regulation of hippocampal glucocorticoid receptor expression. Soc Neurosci Abstr 22:1219.

Liu D, Tannenbaum B, Caldji C, Francis D, Freedman A, Sharma S, Pearson D, Plotsky PM, Meaney MJ (1997) Maternal care, hippocampal glucocorticoid receptor gene expression and hypothalamicpituitary-adrenal responses to stress. Science 277:1659-1662.

Lovenberg TW, Baron BM, deLecea, L, Miller JD, Prosser RA, Rea MA, Foye PE, Racke M, Slone AL, Seigel BW, Danielson PE, Sutcliffe JG, Erlander MG (1993) A novel adenylyl cyclase-activating serotonin receptor $\left(5-\mathrm{HT}_{7}\right)$ implicated in the regulation of mammalian circadian rhythms. Neuron 11:449-458.

Martin KC, Kandel ER (1996) Cell adhesion molecules, CREB, and the formation of new synaptic connections. Neuron 17:567-570.

McCabe JT, Desharnais RA, Pfaff DW (1989) Graphical and statistical approaches to data analysis for in situ hybridization. Methods Enzymol 168:822-845.

Meaney MJ, Aitken DH (1985) The effects of early postnatal handling on the development of hippocampal glucocorticoid receptors: temporal parameters. Dev Brain Res 22:301-304.

Meaney MJ, Aitken DH, Sapolsky RM (1987) Thyroid hormones influence the development of hippocampal glucocorticoid receptors in the rat: a mechanism for the effects of postnatal handling on the development of the adrenocortical stress response. J Neuroendocrinol 45:278-283.

Meaney MJ, Aitken DH, Bhatnagar S, Berkel CV, Sapolsky RM (1988) Postnatal handling attenuates neuroendocrine, anatomical, and cognitive impairments related to the aged hippocampus. Science 238:766-768.

Meaney MJ, Aitken DH, Sharma S, Viau V, Sarrieau A (1989) Postnatal handling increases hippocampal type II, glucocorticoid receptors and enhances adrenocortical negative-feedback efficacy in the rat. Neuroendocrinology 51:597-604.

Meaney M, Aitken D, Sapolsky R (1991) Environmental regulation of the adrenocortical stress response in female rats and its implications for individual differences in aging. Neurobiol Aging 12:31-38.

Meaney MJ, Aitken DH, Sharma S, Viau V (1992) Basal ACTH, corticosterone, and corticosterone-binding globulin levels over the diurnal cycle, and hippocampal type I and type II cirtucisteriud receptors in young and old, handled and nonhandled rats. Neuroendocrinology 55:204-213.

Meaney M, Diorio J, Francis D, LaRocque S, O'Donnell D, Smythe JW, Sharma S, Tannenbaum B (1994) Environmental regulation of the development of glucocorticoid receptor systems in the rat forebrain: the role of serotonin. Ann NY Acad Sci 746:260-275.

Meaney M, Diorio J, Widdowson J, LaPlante P, Caldji C, Seckl JR, Plotsky PM (1996) Early environmental regulation of forebrain glucocorticoid receptor gene expression: implications for adrenocortical responses to stress. Dev Neurosci 18:49-72.

Mellstrom B, Pipaon C, Naranjo JR, Perez-Castillo A, Santos A (1994) Differential effect of thyroid hormone of NGFI-A gene expression in developing rat brain. Endocrinology 135:583-585.

Mitchell JB, Iny LJ, Meaney MJ (1990a) The role of serotonin in the development and environmental regulation of hippocampal type II corticosteroid receptors. Dev Brain Res 55:231-235.

Mitchell JB, Rowe W, Boksa P, Meaney M (1990b) Serotonin regulates type II corticosteroid receptor binding in hippocampal cell cultures. J Neurosci 10:1745-1752.

Mitchell JB, Betito K, Boksa P, Rowe W, Meaney MJ (1992) Serotinergic regulation of type 11 corticosteroid receptor binding in cultured hippocampal cells: the role of serotonin-induced increases in cAMP levels. Neuroscience 48:631-639.

Mitchell PJ, Timmons PM, Hebert JM, Rigby PW, Tjian R (1991) Transcription factor AP-2 is expressed in neural crest cell lineages during mouse embryogenesis. Genes Dev 5:105-119.

Mohammed A, Henriksson B, Soderstrom S, Ebendal T, Olsson T, Seck1 J (1993) Environmental influences on the central nervous system and their implications for the aging rat. Behav Brain Res 57:183-191.
Morgan JI, Curran T (1991) Proto-oncogene transcription factors and epilepsy. Trends Pharmacol Sci 12:343-349.

Nobukuni Y, Smith C, Hager GL, Detera-Wadleigh SD (1995) Characterisation of the human glucocorticoid receptor promoter. Biochemistry 34:8207-8214.

O’Donnell D, Larocque S, Seckl JR, Meaney MJ (1994) Postnatal handling alters glucocorticoid, but not mineralocorticoid mRNA expression in adult rats. Mol Brain Res 26:242-248.

Parent AR, Sharma S, Quirion R, Meaney MJ (1996) Developmental profile of diacylglycerol and inositol phosphate production induced by the stimulation of muscarinic, glutamate, metabotropic, serotonin and endothelin receptors in the hippocampus of neonatally handled rats. Soc Neurosci Abstr 22:1534.

Pennypacker KR, McMillian MK, Douglass J, Hong JS (1994) Ontogeny of kainate-induced gene expression in rat hippocampus. J Neurochem 62:438-444.

Philipp J, Mitchell PJ, Malipiero U, Fontana A (1994) Cell-type specific regulation of expression of transcription factor AP-2 in neuroectodermal cells. Dev Biol 165:602-614.

Pipaon C, Santos A, Perez-Castillo A (1992) Thyroid hormone upregulates NGFI-A gene expression in rat brain during development. J Biol Chem 267:21-23.

Plassat JL, Amlaiky N, Hen R (1994) Molecular cloning of a mammalian serotonin receptor that activates adenylyl cyclase. Mol Pharmacol 44:229-236.

Plotsky PM (1991) Pathways to the secretion of adrenocorticotropin: a view from the portal. J Neuroendocrinol 3:1-9.

Plotsky P, Meaney MJ (1993) Early, postnatal experience alters hypothalamic corticotropin-releasing factor (CRF) mRNA, median eminence CRF content and stress-induced release in adult rats. Mol Brain Res 18:195-200.

Sarrieau A, Sharma S, Meaney MJ (1988) Postnatal development and environmental regulation of hippocampal glucocorticoid and mineralocorticoid receptors in the rat. Dev Brain Res 43:158-162.

Seamon KB, Vaillancourt R, Edwards M, Daly JW (1984) Binding of $\left[{ }^{3} \mathrm{H}\right]$ forskolin to rat brain membranes. Proc Natl Acad Sci USA 81:5081-5085.

Shen Y, Monsma F, Metcalf M, Jose P, Hamblin M, Sibley D (1993) Molecular cloning and expression of a 5-hydroxytryptamine 7 serotonin receptor subtype. J Biol Chem 268:18200-18204.

Smythe JW, Rowe W, Meaney MJ (1994) Neonatal handling alters serotonin turnover and serotonin type 2 receptor density in selected brain regions. Dev Brain Res 80:183-189.

Towbin H, Staehelin T, Gordon J (1979) Electrophoretic transfer of proteins from polyacrylamide gels to nitrocellulose sheets: procedure and some applications. Proc Natl Acad Sci USA 76:4350-4354.

Tsou A, Kosaka A, Bach C, Zuppan P, Yee C, Tom L, Alvarez R, Ramsay S, Bonhaus D, Stefanich E, Jakeman L, Englen R, Chan H (1994) Cloning and expression of a 5-hydroxytryptamine 7 receptor positively coupled to adenylyl cyclase. J Neurochem 63:456-464.

Vallejo M (1994) Transcriptional control of gene expression by cAMPresponse element binding proteins. J Neuroendocrinol 6:587-596.

Viau V, Sharma S, Plotsky PM, Meaney MJ (1993) The hypothalamicpituitary-adrenal response to stress in handled and nonhandled rats: differences in stress-induced plasma ACTH secretion are not dependent upon increased corticosterone levels. J Neurosci 13:1097-1105.

Vizuete ML, Venero JL, Traiffort E, Vargas C, Machado A, Cano (1997) Expression of 5-HT7 receptor mRNA in rat brain during postnatal development. Neurosci Lett 227:53-56.

Wallace C, Withers G, Weiler I, George J, Clayton D, Greenough W (1996) Correspondence between sites of NGFI-A induction and sites of morphological plasticity following exposure to environmental complexity. Mol Brain Res 32:211-220.

Weaver S, Meaney MJ (1997) Environmental regulation of forebrain glucocorticoid receptor development. Curr Opin Endocrinol Diabetes $4: 147-158$.

Wong DL, Siddal BJ, Ebert SN, Bell RA, Her S (1998) Phenylethanolamine $N$-methyltransferase gene expression: synergetic activation by Egr-1, AP-2 and the glucocorticoid receptor. Mol Brain Res 61:154-161.

Worley PF, Baraban JA, DeSousa EB, Snyder SH (1986) Mapping second messenger systems in the brain: differential localizations of adelylate cyclase and protein kinase C. Proc Natl Acad Sci USA 83:40534057. 